\title{
Planning Principles and War Stories: The Perspective of a City Manager
}

\author{
Mary Strenn \\ AICP; BSc. in Urban Planning, Masters in Environmental Studies and Administrative \\ Services. Worked as a city manager in five cities and is an advisory board \\ member of CAED's PDCI - Planning, Design and Construction Institute.
}

\begin{abstract}
The CRP Department invited planner Mary Strenn for a presentation on her professional experience. She allowed us to record her presentation and helped us adapt it for publication. The students were fortunate to learn about her planning principles and how she applied them in several of her professional endeavours.
\end{abstract}

$M$ ost of my career has been in city management. I have served as City Manager in four different cities (and am just starting an assignment as an interim City Manager in a fifth city). My career took me to three states.

You may wonder what a City Manager does. Well, it is a position that is hired by an elected mayor and city council to run the city and advise on policy. In general law cities in California, the only paid staff that can work directly for elected officials is the City Manager and City Attorney (large/charter cities are slightly different).

The concept of City Manager came out of the good government movement of the 1900's to separate the elected and operational posts, to stop patronage in hiring and eliminate favoritism in services. The concept is based on the corporate model where there is a board of directors that sets policy and a chief executive officer who carries it out. It is supposed to promote efficiency and effectiveness as well as provide equality in services. A key objective is to engage the community to encourage involvement in their government. City Managers typically oversee departments of public works, police \& fire, parks \& recreation, planning engineering, finance, sometimes libraries and public utilities.

I am an AICP certified planner. My background is in city planning although I spent most of my career either working out of the City Manager's office or being the City Manager myself. I never did current planning or sub-divisions review and would not be very skilled at it; I was usually tasked with long term or policy planning.

City Managers spend the majority of their time on public safety - because that is where the most things can go wrong. But planners spend the majority of their time on development projects that emphasize community engagement among many high stakeholders. Planning employees are hired on a merit basis, usually covered by civil service, therefore, you are hoping for a certain level of professionalism.
Today I'll briefly touch on my perspective of planning as well as some principles I think are important in the planning field.

From the perspective of planning, I am often surprised that people are going into the field. Planning is the antithesis of the carefree lifestyle that most value, where they do not have to think a lot. In fact we do not want to live in a community that has just been haphazardly developed, just as you do not want a career that is just going to happen. As much as we value a carefree philosophy, it is not how we want to run our lives or cities. Planning is tough. It is an active not a passive activity. Going back to the idea of the examined life, planning requires critical thinking. It requires thinking about everything when others do not.

An article featured in the Wall Street Journal called The Pros and Cons of Cyber English by David Gelernter states that, "time has in a sense two dimensions: the now and the not now. We know what the now is but the not now is everything else. Everything that has come before and everything that will come after." Planners are required to think of the now and the not now (even though string theorist would argue that there are more dimensions). Planners will come into contact with people like developers that are going to have better ideas of what the public wants now. The planner is going to have to think about what happened in the past, what is going to happen in the future, and what the consequences are. The planner needs higher ethical standards and a longer view.

Planning is a great field. It is not like manufacturing widgets. Throughout your daily life you will see some relation to what a planner does and that is very rewarding. This is particularly true of physical planning, although it is also true of the business world. Planning for the physical world is very worthwhile.

Think of the old planning masters principle, "make no small plans". That does not necessarily mean what you put forth. One of my strengths is to always plan big and implement small. This 
is the first principle I share with you. It is politically and fiscally difficult to get all elements of a project done at once. Take for example the City of Chicago; they are still implementing their river front plan. It has gone through a lot of evolutions in architectural trends. A river tour called the 'Architectural River Tour' will take you up the river and point out different styles of architecture from the past 100 years. They explain how originally buildings were oriented with their backs to the river and were later turned to face the river in order to take advantage of the amenity and architectural facades. This is a project that has taken a tremendously long time. It was done in segments and had its share of fits and starts.

One of my first big projects was in Peoria, Illinois, known as the home of Caterpillar Tractor Company; it is a working class community of about 130,000 . The City had a neglected riverfront going through industrial and rail yards. However, there were some very vocal and visionary people that wanted to see something done to the riverfront. Frankly, I was very junior and I believe I was assigned to keep those people occupied and quiet. They were not very powerful. They were respected but not powerful. They did not have the money or the votes, but they were very enthusiastic and had staying power. By the time I left to come to California, we had all the land in public ownership, we had brought in the weekend warriors (the Seabee Reserves) who came in and tore out the rail yards for free. We worked with some of the industries to obtain strips of land in order to have continuous parkways. We renovated a former train station to be a restaurant. We even set up a light rail line to go up to some industries further along the river.

When I had the project we had a hundred million dollars, a substantial amount of money back then. Every ten years or so I would return and see the riverfront extended, kind of like San Antonio. It has changed in form a lot. It is not the plan in its original form. It has evolved with time because it takes a long time. What kept it going was the enthusiasm on my part because I was young and maybe didn't know any better, but also the enthusiasm of the people who wanted to see it done. In this line of work, you will be advised to collaborate with the community and to find out what they really want. Not only is it the right thing to do but also it is the best way to carry a plan forward. The plan will transcend you. It will transcend elected officials. It will transcend everyone. Therefore, its just good business to engage with the community.

The second principle is to have visionary plans. This will be a challenge because you are planning for now and tomorrow. It is not always easy. Often the most novel plans arise from rapidly transitioning communities. For example, ethnic majority or income level may change in the community. Those living in a community at one point in time may not be living there in the future and therefore will not represent the views of the future majority.

Planners are required to think of the now and the future. This has to be handled delicately because the future residents will usually not be the people in power or the people with money.

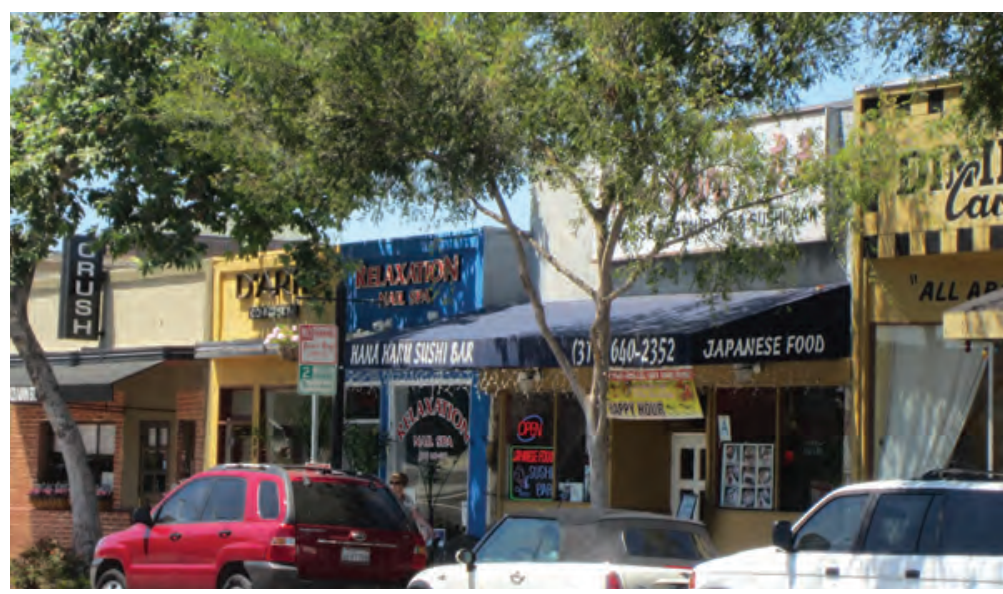

Figure 1: Mixing retail and restaurants in the revitalized downtown, El Segundo.

You need to some how show that it is in the best interest of everybody that this be a living community way into the future.

When you think of some of our great cities, San Francisco is a good example, the neighborhoods have transcended. This does not mean that they have gotten worse. It means they have transcended. A problem for planners is recognizing that downtowns have not lost their function or purpose but that the function needs to change. Too often it is the planners pushing for a downtown defined by a commercial core. Instead, planners must figure out how that downtown is going to change function without changing its purpose. The downtown maintains its purpose all along. The purpose is to be the focal point or the heart of the community. Rarely, is the purpose to be the financial heart of the community. For example, El Segundo is a small community of about 20,000 residences. However, the City has big industries that bring in 80,000 people a day. El Segundo's commercial/retail area was a classic downtown. However, it cost more money to service the downtown than it ever generated in the way of sales tax. Yet, it was the focal point. When the downtown started looking seedy, people thought the city was seedy. If we had been able to let the downtown change its function while still maintaining its purpose, we could have gotten ahead. Nowadays, you see downtowns that act more as cultural centers, government centers or educational centers than as commercial centers. I think this is a good thing. Downtowns are still the focal point but with different functions.

Another principle is to look for your champions. You cannot be the evangelist. You may want to because it is your plan and you know the value of it. However, you really need somebody who will be the champion, either a neighborhood group or a powerful mayor. Probably, a developer is not your best option. It is good to have someone in your corner that will go out and excite others on what is going to be happening.

You also want to think about the long-term effects. I worked on a downtown design with a specific plan, plenty of money and 
a champion in the form of a very active and charismatic mayor. He did a good job of convincing potential property owners to invest in the downtown.

Things changed in interesting ways, as it often does in small downtowns when a city has multiple parcels owned by the descendants of the original merchant owners. The current owners may have inherited the property and are content with collecting low-level rent. They might have this mentality that if it is not causing them problems why should they invest in the property. In my experience when the mayor drummed up moneyed interests the downtown became a speculation market. Property changed hands two, three times - becoming very expensive. The new owners were professionals expecting to get high rents. Ultimately, we were successful to a fault. We wanted to nurture small businesses but the small businesses were not able to afford the new high rents.

A study done years ago in Boston put forth the idea of the "golden mean". You want neither a rapidly escalating nor deescalating market because both are just as dangerous. We always think it is good when it is escalating and bad when it is deescalating. The "golden mean" is stability.

I think that one of the most important things we can do, whether we are in the planning field or not, is to protect what is in the public domain. We will go on about how we do not have land for new highways, rail or bikeways, or we do not have animal corridors. In fact we do. It just may be under control of some other agency, the quasi-public sector, a utility, flood control district, or agricultural water district. It may be a railroad where the public has reverter rights. The land is there, we just lack the political will to make it multi-use.

I have always felt that there ought to be some penalty for any land that is held for a single use. Yes, that means the Sierras can still be pristine. They will just have to pay something. It does not mean that a flood control district can make sure that there is no bike path along it. They would have to pay a premium for hav-

Figure 2: Sidewalk dining and new downtown development in El Segundo.

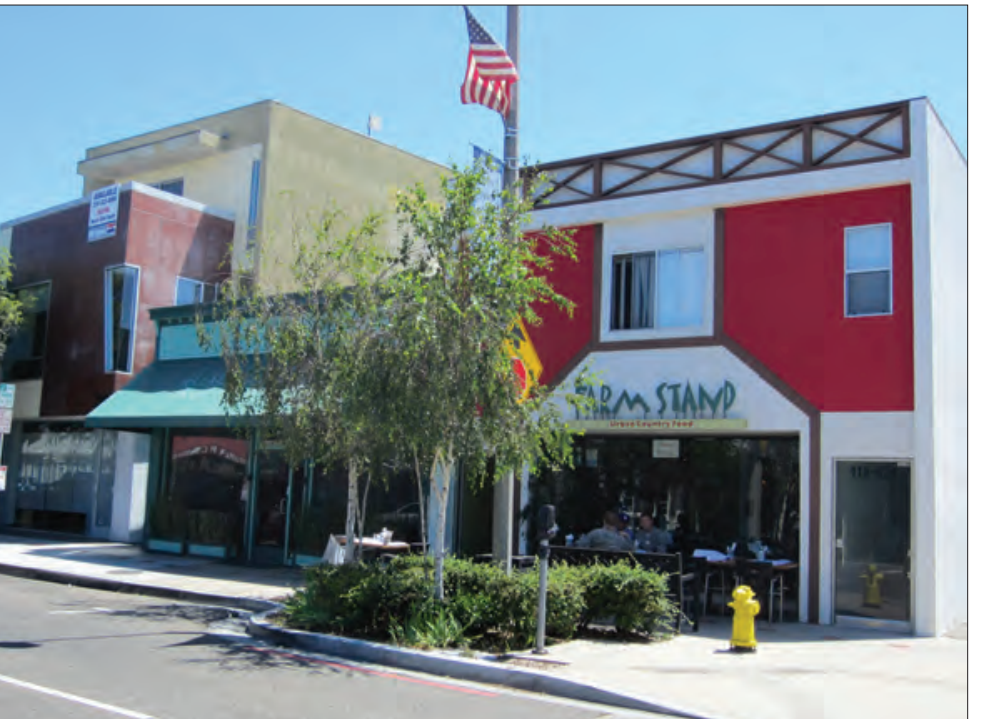

ing the right of exclusivity. Therefore it is not an absolute problem; it is a problem of vision. It is a tough one because of a bunker mentality. If you are going to have visionary plans you must have enough enthusiasm to get around this bunker mentality.

A good example is the LA River. Years ago it was converted to a concrete slew that goes from the very top twenty-five miles down to the ocean. All of that will start to grass over in time. The flood control districts and the department of water and power would get out there and bulldoze any greenery that came around. With enough public pressure, a portion of the river, maybe four miles, was allowed to green over which means it does not carry as much water as quickly, although it carries it so that it does not flood off to the side when there are heavy rainstorms. When you are in those sections now there are blue herons, whooping cranes and various other wildlife, plus the homeless. In addition, there is a bike path. Unfortunately, the bike path is next to a freeway. Even though it is safe, the noise is deafening and air quality is poor. On the opposite side, is a maintenance road that is closed to the public. Maintenance crews use the road maybe once a week at most. With enough public pressure, the bike path and maintenance road could switch sides, putting the infrequently used maintenance road next to the freeway. This will take public pressure and also somebody thinking ahead convinced that this is something that should be done.

When you take your bike along there now you see little pocket parks have been established moving about a mile at a time further and further down the river. Along this line, one of the principles is to do long range planning for every form of transportation, including: roadways, bikeways, walking paths, light rail, heavy rail, etc. A project in the City of San Fernando was alongside an active rail line. We were told that it should not be done because it was unsafe and somebody could get killed. Well in fact, people who get killed on train tracks are usually crossing when they know they are not supposed to, inebriated or they are being a bit rowdy. It does not tend to be pedestrians who are paying attention. There is now a walking/bike path along the railroad that is actively used and has not seen any accidents. It is just one of those urban myths that we carry with us.

Planners need a long-term view of the linkages of transportation. During WWII, Berlin's subway system snaked through the divided city. Half of the city was Allied territory and the Russians controlled the other half. Therefore, they bricked up certain stops enabling the subway to continue to pass through but not allowing commuters to get off in certain areas. Planners on both sides always believed in a reunified Germany and when that took place it was within months that the bricks were taken down and the stops were open again. Planners are the ones thinking about the future even in the most awful times.

My last principle is, market forces are not evil. The government does not have the money to implement everything. A plan needs to go along with economic forces. There is nothing wrong with a profit motive; in fact it is what gets the public sector to put money on the table. It is not a dirty word. Economic 
incentives are often very innovative. You will find planners in this school of thought working for developers. However, it is important to remember that developers are planning for the now and planners need to plan for the future. What might be a good idea now may not be sustainable later. Planners need to hold the development community to this idea.

Years down the line, what are we going to do when festival centers are no longer in vogue? What will it transition into? What are we going to be left with? Will we be left with an indoor mall that we want to make open air? What is going to happen in the citywide context? Planners need to think beyond jurisdictional boundaries even if it is beyond the scope of the plan. The public does not think about city limits. We need to think about if our plans are connected to plans elsewhere. As much as you may not want to think about jurisdictional boundaries, there are times when it will be well worthwhile to do so.

And times when we emphasize those boundaries. For instance, a gateway project is an affordable way to brand a community. It is a plan with the intent to stand out and be different from what is across the street. This can be done by putting in wayfinding elements, monuments, etc. It may be contradictory but it is the manner in how a place forms its identity.

The first City Managers started out as Public Works directors because much of what they did had to do were things such as: snow removal, cleaning streets, making sure the sewers were there, making sure water was provided, etc. It evolved from there into finances and then it was a matter of how do we pay for our cities.

City Managers are those who have good financial skills. In my opinion, planners do not have enough of a financial background. But, City Managers who come from the planning field often are visionary and have a long-term view. I'm obviously biased, but I think the planning perspective is the best you can have for a City Manager. Even if you are a first level planner trying to get a project approved or working for a consulting company you will have to deal with the community and their politics and this will require both skill and vision.

\section{Questions and Answers}

Question 1: Faculty: In regards to the El Segundo project, how much did you invest in city marketing to attract investment?

Mary Strenn: El Segundo is a unique city in that it has a very large international business community and small residential community. We invested a lot. We had more fortune 500 headquarters in El Segundo than in all of LA. I think a lot of communities try to invest in marketing but on the cheap. That is why Gateway projects are so valuable because it identifies you as being different from your neighbor. El Segundo hired an upscale advertising firm that came up with this campaign of "We're not L.A." I personally thought it was a terrible campaign but it was very effective. I thought it was a bad neighbor policy, no way to get along. But it was successful. While every community invests in marketing, the dollar amounts are going to be different.

Question 2: Faculty: Speaking as the Department Head of City and Regional Planning, I am very interested in your comment about the financial acumen. What do planning students need to know? And how can our faculty help students take a finance track? Do you recommend one course or two? Or perhaps getting something going with the Business School?

Mary Strenn: About fifteen or twenty years ago, USC revamped their Urban and Regional Planning program. In the end most people assessed that it was almost a real estate program. I do not think that is what it is supposed to be but you have to have some understanding of the dollars and cents behind what makes development of private property work. You also need to have some financial knowledge when you are talking to a company on a project. As far as doing the deal on a major project, you will always have a financial expert working on the project. As a planner you do not have to have that level of financial expertise. However, it is important to know how businesses work, how balance sheets work, how land sales work.

Comment 1: Faculty: A metaphor I like to tell new students in the Planning Department is, "a planner is a conductor of an orchestra. He does not have to play every instrument well but he has to know how to play every instrument to some extent." So I think understanding a little bit of financing, real estate, and everything that planners deal with on the job is important to include in planning education. I think your comment in that regard is very good and I think as faculty it is something we need to pay more attention to.

Comment 2: Faculty: Yes, as faculty I think we need to find the right level of proficiency that students need to have in these areas. We presently have a course that includes real estate and housing fiscal analysis but it may lack analysis from the city manager's perspective.

Figure 3: Mid-block punch-through to parking garage and a community mural in El Segundo.

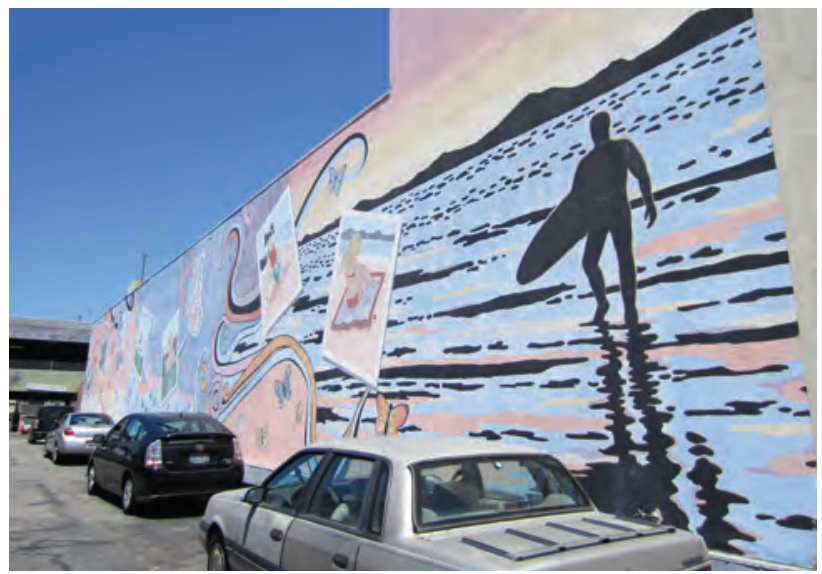


little harder to work out but as long as there is public pressure it can be done. There are a lot of reasons why you would want to keep it just for you: it is easier, less complex; you are not subject to somebody else's liability. Why should you want to do it unless you are forced to?

Comment 4: Faculty: Perhaps liability is the worse problem. Financially, you can in a way convince the money. Look at the whole redevelopment reform movement. When it started no port wanted to let it happen. It took a lot of work on the part of the cities to convince the port authority that they could make money out of port redevelopment and move cranes and everything to deeper waters. Every port passed through the same process and if it were not for the financial possibilities they would never give up.

Mary Strenn: A classic example is in Long Beach, one of the most polluted areas around. San Pedro has the worst air pollution in the state of California because of the rail and ship activity. They are trying a waterfront project and it has been very contentious but it is making progress. It is not easy. In some other countries they do a better job of making sure there isn't as much of this bunker mentality.

Comment 5: Student: As a young planner, I think the point you make about incremental implementation is a healthy reminder that nothing happens over night. This is a truth of life that we are not going to see change happen as quickly as we hope or wish. There are economical variables and political underpinnings that influence the rate of progress. There is something in here about not becoming discouraged and not becoming overwhelmed by the voice of the naysayer. It's important to remember, it all takes time.

Comment 6: Faculty: You touch on something that academia deals with everyday, especially in design studios. You have to be in between teaching them or making them decide something that can be done now but you have to have the perspective of the big plan. Otherwise why are you doing it?

Comment 7: Faculty: A point that has been striking me is this issue of leadership, not just the skill acumen but also the leadership. The vision is about leadership and understanding that you are going to get the critique and trying to be eloquent about what you are saying. Being able to withstand the naysayers. Having power of conviction makes for good leadership and being able to communicate that consistently even if things are not going well.

Mary Strenn: Sometimes your elected leadership has more of a handle on motivation because they come from a perspective that they will be in office for two years - but plan implementation is twenty. So they are wondering what is in it for me. People often wonder why things do not work in Mexican towns. First, they do not have control of their local money, every two years everybody picks up and goes, they take the records with them; the next people who come in have no interest in fulfilling the plans of the previous people. It is a very difficult environment. It takes real steward to work tirelessly for two years than hand it off to someone else. That's a pretty noble person who can do that.

Mary Strenn has been a professional in local government management for over 30 years. She has served as the city manager or chief executive of 4 cities in California and has been the executive director of redevelopment agencies in 3 cities. She has worked in three states.

Mary has been in state and national leadership roles in the city management profession. She has been President of two League City Manager Area Groups, served on the Board and has been on ICMA Committees. She is a former Executive Board Member for the Los Angeles Economic Development Corporation and Past Board President of Public Service Skills, Inc.

Her educational background is a Bachelor of Science in Urban Planning and a Masters in Environmental Studies/Administrative Services. She is an AICP certified planner and is credentialed with the International City/County Management Association (ICMA).

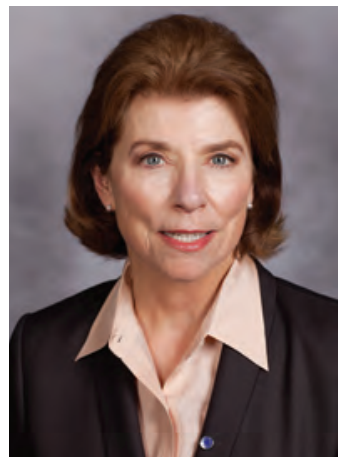

